\title{
慢性血液透析患者の左室心筋重量に関係する因子の検討
}

谷仲 肇子 石光 俊彦高橋 正 樹南順 -
小野 英 彦
獨協医科大学循環器内科

key words：血液透析, 左室心筋重量, 血圧, アンジオテンシンII, ACE 遺伝子多型

〈要旨〉

慢性血液透析患者において左室心筋重量の増加と関係する因子を検討した，安定した維持血液透析下にあり，虚 血性心疾患や心䁍弁膜症を合併しない 166 例（男 80 例，女 86 例，年齢 $56 \pm 1$ 歳）を対象として心エコ一検查を行 い左室心筋重量係数 (LVMI) を算出した。患者の身体所見, 病歴, 一般検査所見とともに, 血漿アンジオテンシン II (A II) 濃度および ACE 遺伝子型を調査し, LVMI との関係を検討した。身体所見および背景因子の中では血圧が LVMI と強い相関を示し (収縮期血圧 $r=0.254, p=0.001$; 拡張期血圧 $r=0.261, p<0.001$ ), 年齢, 性, Body mass index (BMI)，腎不全の原疾患，透析年数，喫煙，飲酒，眽拍数，透析間の体重増加などの項目と LVMI の間には有 意な相関は認められなかった。検査所見では血漿 $A I I （ r=0.184, p=0.020)$ が有意に相関し, 肝酵素, BUN, 血 清 $\mathrm{Na}, \mathrm{K}, \mathrm{Ca}, \mathrm{P}$ ，ヘマトクリット， $\beta_{2}$ ミクログロブリン, ACE 遺伝子型などはLVMI と有意な関係を示さなかっ た. 慢性血液透析患者においては，血圧がLVMI に影響する主要な因子であり，これとともにレニンーアンジオテン シン系の亢進がLVMI の増加に関係すると推測される.

\section{Analysis of factors influencing the left ventricular mass in chronic hemodialysis patients}

Hatsuko Yanaka, Toshihiko Ishimitsu, Masaki Takahashi, Junichi Minami, Hidehiko Ono Department of Hypertension and Cardiorenal Medicine, Dokkyo University School of Medicine

Incidences of cardiovascular diseases are increased in hemodialysis patients, and the existence of left ventricular hypertrophy is one of the major risk factors for cardiovascular events. The purpose of this study is to elucidate the factors contributing to the development of left ventricular hypertrophy in hemodialysis patients. Left ventricular mass index (LVMI) on echocardiography was measured in 166 chronic hemodialysis patients (80 men, 86 women, age $56 \pm 1$ years) without ischemic or valvular heart disease, and the correlations with physical and laboratory findings including the renin-angiotensin system were analyzed. Among the physical findings, systolic and diastolic blood pressure strongly correlated with LVMI $(r=0.254$ and $r=0.261$, respectively, $p=$ 0.001 ). Factors such as age, duration of dialysis, cause of renal failure and inter-dialysis weight gain did not significantly correlate with LVMI. Regarding laboratory data, plasma angiotensin II (A II) showed positive correlation with LVMI $(r=0.184, p=0.02)$. However, insertion/deletion ( $/ / D)$ polymorphism of ACE gene did not significantly affect LVMI (II $152 \pm 7$, ID $151 \pm 6$, DD $142 \pm 9 \mathrm{~g} / \mathrm{m}^{2}$ ), and plasma A II was not significantly different between the genotypes (II $15.8 \pm 2.8$, ID $12.4 \pm 1.5, \mathrm{DD} 14.8 \pm 3.1 \mathrm{pg} / \mathrm{mL}$ ). It is suggested that blood pressure is an important factor contributing to the increase in LVMI in chronic hemodialysis patients and that activation of the renin-angiotensin system may participate in the development of left ventricular hypertrophy.

\footnotetext{
石光 俊彦 獨協医科大学循環器内科 $\quad$ 个 321-0293 栃木県下都賀郡壬生町北小林 880

Toshihiko Ishimitsu Tel :0282-87-2149 Fax :0282-86-1596 E-mail : isimitu@dokkyomed.ac.jp

〔受付：平成 13 年 12 月 12 日, 受理: 平成 14 年 3 月 11 日〕
} 


\section{緒言}

透析患者に予いては心血管疾患が感染症とともに死 因の中で大きな割合を占めている1)，Framingham 研 究2)などの疫学的調查により心肥大が心血管疾患発症 の主要な危険因子であることが示されているが，透析 患者においても左室肥大が存在すると心血管疾患発症 のリスクが高く，予後に影響する重要な因子の一つで あることが明らかにされている3,4). 特に透析患者にお いては左室肥大の頻度が高く，心血管疾患の抑制执よ び尒後の改善を図る上で心肥大の進展を抑制すること が重要であると考えられる。そのためには心筋重量の 増加に寄与する因子を同定し，改善することが効果的 であると思われる。

心肥大の進展には压負荷のみならずレニンーアンジ オテンシン系などの神経体液性因子が関与することが 推定されている。本研究では，慢性血液透析患者にお いてレニンーアンジオテンシン系を含め左室心筋重量 に関係する因子を検討した。

\section{I . 対象および方法}

対象は安定した慢性維持血液透析下にあり, 弁膜症 や虚血性心疾患を合併しない男性 80 例, 女性 86 例で, 年歯令は平均 $56 \pm 1$ 歳であった。調査項目は，飲酒，喫 煙などの生活習慣，血圧，体重などの身体所見，一般 血液検查に加えて，血漿アンジオテンシンII (AII) 濃 度の測定およびアンジオテンシン変換酵素 (ACE) の 遺伝子型の決定を行った。血圧は各透析前に 10 分間の 安静の後に仰臥位にて測定し，2週間の血圧值の平均 を評価に用いた。
透析終了後患者がドライウェイトにある時に, 経胸 壁心エコー図検查を施行し左室心筋重量係数を計測し た。心エコー図の記録には, $2.5 \mathrm{MHz}$ の探触子を接続 した超音波診断装置（SSH-260 A，東芝）を使用した。 傍胸骨 $\mathrm{M}$ モード像で心室中隔壁厚, 左室後壁厚および 左室拡張末期径を計測し, Devereux $5^{5}$ )の式 (左室心 筋重量 $=0.8[1.04\{$ (心室中隔壁厚 + 左室拡張末期径十

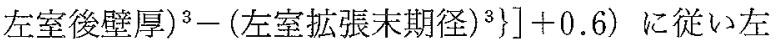
室心筋重量を計算した。これを体表面積 $\left(\mathrm{m}^{2}\right)$ で除し, 左室心筋重量係数 (LVMI) とした。

透析前, 10 分以上の臥位安静の後, 静脈側穿刺時に 採血し, ただちに承冷・遠沈して血獎 AII濃度を既報 のラジオイムノアッセイで測定した ${ }^{6)}$ 。また，対象者よ りゲノム解析の承諾を得て, 未梢血白血球より EasyDNA キット (フナコシ製)を用いてグノム DNA を抽 出し, Rigat ら ${ }^{7)}$ および Shanmugam ら ${ }^{8)}$ の方法に従い insertion（I）および deletion（D）のACE 遺伝子型 を決定した。

データは平均士標準誤差で表した。2 変数の相関は 回帰直線解析で評価し, 左室心筇重量係数を目的変数 とした多変量の相関の検定には重回帰分析を用いた。 $\mathrm{p}<0.05$ を有意差の判定とした。

\section{II。結果}

表 1 に対象とした透析患者の身体所見沶よび背景因 子を男女別に示した。年齢や透析継続年数に男女差は なかったが, Body mass index（BMI）は男性の方が やや大きく，飲酒や喫煙習慣を持つ者も男性に多く認 められた，腎不全の原疾患は，男女とも，60〜 70\%が 慢性糸球体腎炎，20～30\%が糖尿病性腎症で，有意な 違いはなかった。血圧は収縮期血圧が男性の方が高く，

表 1 Clinical characteristics of the study subjects.

\begin{tabular}{|c|c|c|c|}
\hline & 男 $(n=80)$ & 女（n=86） & $\mathrm{p}$ 值 \\
\hline 年齢（歳） & $55.6 \pm 1.3$ & $55.4 \pm 1.4$ & \\
\hline Body mass index $\left(\mathrm{kg} / \mathrm{m}^{2}\right)$ & $21.3 \pm 0.3$ & $20.0 \pm 0.3$ & 0.002 \\
\hline 原疾患 慢性糸球体腎炎 & $48(60.0 \%)$ & $56(65.1 \%)$ & \\
\hline 糖尿病性腎症 & $25(31.2 \%)$ & $20(23.3 \%)$ & \\
\hline その他 & $7(8.8 \%)$ & $10(11.6 \%)$ & \\
\hline 透析継続年数（年) & $5.8 \pm 0.5$ & $6.9 \pm 0.6$ & \\
\hline 飲酒習慣 $(+/-)$ & $26 / 54$ & $10 / 76$ & 0.001 \\
\hline 喫煙習慣 $(+/-)$ & $43 / 37$ & $9 / 77$ & $<0.001$ \\
\hline 収縮期血压，(mmHg) & $159 \pm 2$ & $153 \pm 2$ & 0.016 \\
\hline 拡張期血圧 $(\mathrm{mmHg})$ & $82 \pm 1$ & $80 \pm 1$ & \\
\hline 脈拍数（bpm） & $77 \pm 1$ & $78 \pm 1$ & \\
\hline 透析間体重増加率（\%） & $5.3 \pm 0.2$ & $5.9 \pm 0.2$ & 0.005 \\
\hline
\end{tabular}

(平均土標準誤差) 
表 2 Correlations of left ventricular mass index with background characteristics and physical findings.

\begin{tabular}{lrc}
\hline & 相関係数 & $\mathrm{p}$ 值 \\
\hline 年齢 & 0.039 & $\mathrm{NS}$ \\
性 & 0.011 & $\mathrm{NS}$ \\
Body mass index & -0.085 & $\mathrm{NS}$ \\
原疾患 & -0.023 & $\mathrm{NS}$ \\
透析年数 & -0.100 & $\mathrm{NS}$ \\
飲酒量 & 0.048 & $\mathrm{NS}$ \\
喫煙量 & -0.039 & $\mathrm{NS}$ \\
収縮期血圧 & 0.254 & 0.001 \\
拡張期血圧 & 0.261 & $<0.001$ \\
䂡拍数 & -0.013 & $\mathrm{NS}$ \\
透析間体重増加率 & 0.022 & $\mathrm{NS}$ \\
\hline
\end{tabular}

表 3 Correlations of left ventricular mass index with laboratory findings.

\begin{tabular}{lrc}
\hline & 相関係数 & $\mathrm{p}$ 值 \\
\hline ヘマトクリット & 0.040 & $\mathrm{NS}$ \\
血清 $\mathrm{GPT}$ & -0.001 & $\mathrm{NS}$ \\
血清アルブミン & 0.043 & $\mathrm{NS}$ \\
血液尿素窒素 & -0.007 & $\mathrm{NS}$ \\
血清 $\mathrm{Na}$ & 0.019 & $\mathrm{NS}$ \\
血清 $\mathrm{K}$ & 0.068 & $\mathrm{NS}$ \\
血清 $\mathrm{Ca}$ & -0.039 & $\mathrm{NS}$ \\
血清 $\mathrm{P}$ & -0.039 & $\mathrm{NS}$ \\
血清 $\beta_{2}$ ミクログロブリン & 0.019 & $\mathrm{NS}$ \\
血漿アンジオテンシンII & 0.184 & 0.020 \\
$\mathrm{ACE}$ 遺伝子型 & -0.051 & $\mathrm{NS}$ \\
\hline
\end{tabular}
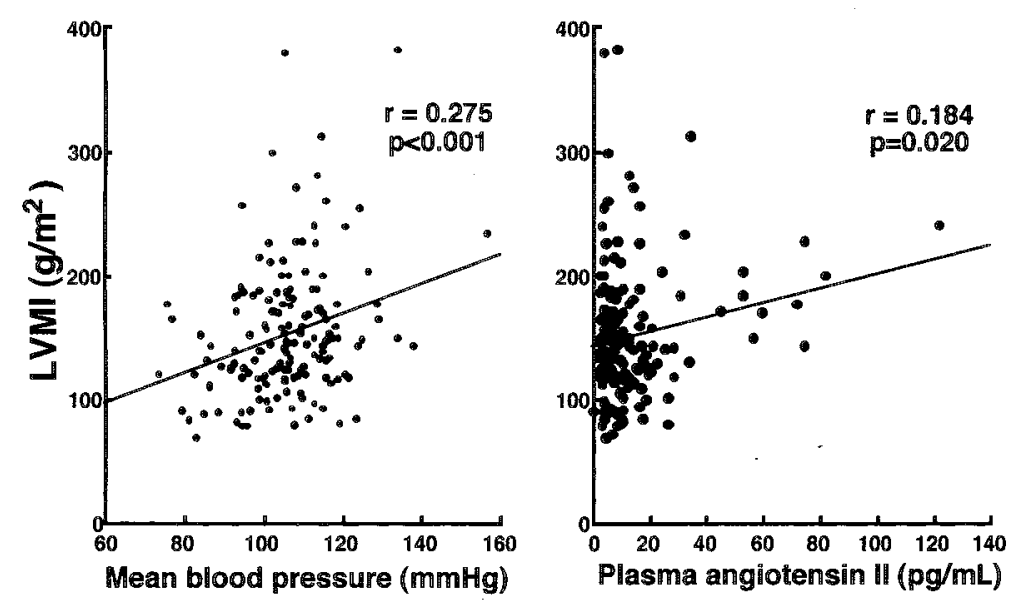

図 1 Correlation of left ventricular mass index (LVMI) with blood pressure and plasma angiotensin II in patients on chronic hemodialysis.

透析間の体重増加率は女性の方が多かった。

対象とした 166 例のうち 112 例 (67.5\%) が利尿薬 以外の降圧薬を服用していた。そのうち 46 例 (27.7\%) が単剂，42 例 (25.3\%) が 2 剂， 24 例 (14.5\%) は 3 剤以上の降圧薬により加療されていた。降圧薬の種類 は, $\mathrm{Ca}$ 拮抗薬が 102 例 $(61.4 \%)$ と最も多く, $\mathrm{ACE}$ 阻 害薬 44 例 $(26.5 \%), \alpha$ 遮断薬 31 例 $(18.7 \%), \beta$ 遮断 薬 17 例 $(10.2 \%)$ がこれに続き，中枢性交感神経抑制 薬などその他の降圧薬が 16 例 $(9.6 \%)$ に投与されて いた，AII受容体拮抗薬を投与されている症例はな かった. ACE 阻害薬服用群と非服用群の血漿 A I 濃度 は，それぞれ $16.8 \pm 3.2 \mathrm{pg} / \mathrm{mL}$ および $13.4 \pm 1.4 \mathrm{pg} /$ $\mathrm{mL}$ と有意差は認められなかった。

表 2 に対象とした透析患者の身体所見や背景因子と LVMI との関係を個別に検討した結果を示すＬVMI は収縮期および拡張期血圧と強い相関を示したが，年 齢，BMI，透析繼続年数や透析間の体重増加度との間 には有意な相関は認められなかった。
表 3 に各種の検査所見とLVMI との関係を示した。 ヘマトクリットや一般血液生化学所見と左室心筋重量 の間には有意な相関は認められなかった。レニンーアン ジオテンシン系の因子については，血漿 A IIがLVMI と有意な相関を示したが, ACE 遺伝子型は有意な関係 を示さなかった。

図 1 の左は横軸に平均血圧, 縦軸に LVMI を, 右は 横軸に血漿 AII, 縦軸にLVMI をプロットしたグラフ であるが，LVMI は血圧および血漿 A II と有意な相関 を示した。

表 4 に LVMI に影響する因子をステップワイズ重 回帰分析により解析した結果を示すが，各種の因子の 中で血圧が LVMI と最も強く相関し，血獎 AII も，他 の因子の影響を補正した後においても，LVMI と有意 な相関を示した。

図 2 は対象とした透析患者を $\mathrm{ACE}$ 遺伝子型により 分け，血漿 AII濃度および LVMI を比較したグラフで

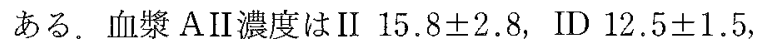


表 4 Stepwise multiple regression analysis of factors correlated with left ventricular mass index.

\begin{tabular}{lcc}
\hline & 標準相関係数 & $\mathrm{p}$ 值 \\
\hline 平均血圧 & 0.285 & 0.002 \\
血漿アンジオテンシン II & 0.179 & 0.041 \\
\hline
\end{tabular}

DD $14.7 \pm 3.0 \mathrm{pg} / \mathrm{mL}$, LVMI は II $152 \pm 7$, ID $151 \pm$ 6, DD $142 \pm 9 \mathrm{~g} / \mathrm{m}^{2}$ といずれも ACE 遺伝子型により有 意な違いは認められなかった。

\section{III. 考 察}

本研究において，慢性血液透析患者の左室心筋重量 に関係する因子を検討した結果，各種の独立変数の中 で血圧が LVMI と最も強い相関係数を示した。心工 コー図で左室心筋重量を検討した過去の多くの報告で は，非粲不全の集団においては血圧が左室心筋重量の 増加に寄与する主要な因子であることが多く示されて いるが9,10)，透析患者における血圧と左室心筋重量の関 係についての成績は必ずしも一定していない11 14)。 こ れには透析患者の血圧が透析間の体重増加の影響を受 け変動が大きいことが関与する可能性が考えられる。 この点に関しては，携带式自動血圧計を用いて透析患 者の血圧をモニ夕ーし，24 時間の平均血圧が左室心筋 重量と良い相関をもつことを観察した成績がいくつか 示されている15,16).24時間血圧のモニタ一を行わなく ても，透析前の血圧測定を繰り返し，その平均值が 24 時間血圧と同様に左室心筋重量と良く相関することも 報告されている ${ }^{17,18)}$ 。本研究で用いた血圧值は 2 週間 の透析前血圧を平均したものであり，より正確に個体 の血圧值を反映していたと考它られる。

これに対し，透析患者の予後と血圧の関係は直線的 でなく，高血圧のみならず低血圧も心機能障害の存在 を反映し予後不良と関係する因子であることが示され ている ${ }^{19,20)}$ ，特に透析後も高い血圧を呈する場合ある いは透析前に血圧が低值である場合にリスクが増加す るようである。

また，透析患者では透析間に体重が変化するため， 左窒心筋重量との相関を検討する際には，心エコ一図 を記録する時間により計測值が影響を受ける可能性が 㐫る. Harnett ら ${ }^{21)}$ の検討によれば, 透析前後で左室拡 張末期径は減少するものの，左室壁厚の増加は有意で なく，結果として左室心筋重量の計算值が減少する傾 向を示すことが報告されている。本研究においては心 エコー図の記録は透析後ドライウェイト時に行われた

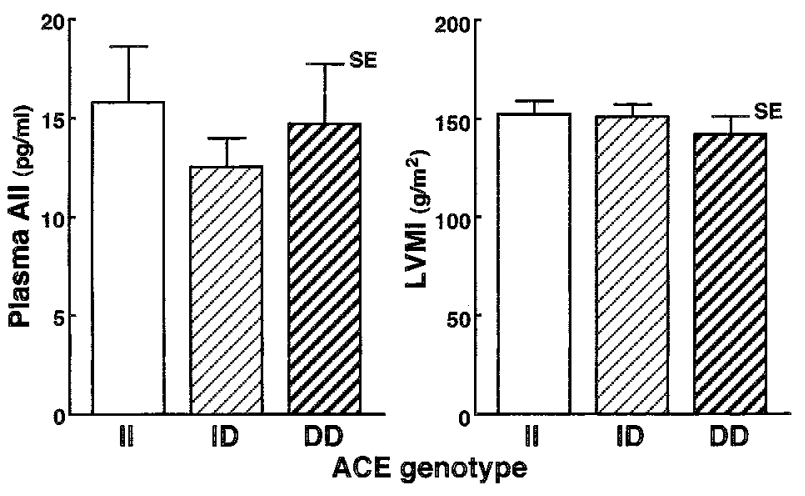

図 2 Plasma angiotensin II (AII) concentration (left panel) and left ventricular mass index (LVMI) (right panel) in chronic hemodialysis patients grouped by ACE genotype.

ため体重の変化による計測值への影響は少ないと思わ れるが，過去の研究において必ずしも血圧と左室心筋 重量の相関が有意でないことには，血圧測定に加え， このような心エコー図記録上の問題が関与する可能性 が推測される。

透析患者に抒いては，正常血圧であっても左室肥大

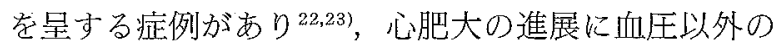
因子が関与すると推測される。過去の成績では，年歯令， ヘマトクリットや透析間の体重増加と左室心筋重量の 間に有意な相関が観察されているが11,24,25)，本研究に おいてはこれらの因子の影響は有意ではなく，心肥大 との関係については血圧が主要な因子であると思われ る。また，貧血の進行に対するエリスロポエチン投与 や体重増加に伴う循環血液量の増加好血圧を上昇させ る原因となるため，これらの因子も血圧の上昇を介し 左室心筋重量の増加に寄与する可能性が考えられる。

心筋重量の増加には圧負荷や容量負荷などの物理的 因子の他に，カテコラミン，レニンーアンジオテンシン 系などの神経内分泌系や体液性因子が関与することが 推定されている。特に AII は，in vitroの実験系にお いて，心等細胞の肥大や間質線維芽細胞の増殖を促進 し26 29)，心肥大の進展に寄与すると考えられる。臨床 に扔いても，多くの研究の結果を総合して解析したメ タアナリシスによれば，各種の降圧薬の中で ACE 阻 害薬が心肥大の退縮効果に優れることが示されてお

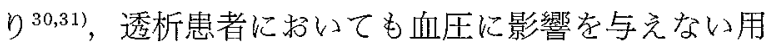
量の ACE 阻害薬の長期投与によって心肥大の退縮が 起こることが報告されている32).さらに透析患者にお いて血漿レニン活性が高值である活ど左室肥大を呈す る頻度が高いことが観察されており ${ }^{33)}$ ，循環血液中に おけるAII 産生の律速段階がレニン活性に依存する 
ことを考慮すると到, 本研究において血漿 AII と LVMI の間に血圧とは独立して正相関が認められた ことは, 透析患者における心肥大進展の病態にレニンー アンジオテンシン系の因子が関与することを支持する 成績であると思われる。

各種の降圧薬の中で AII の産生を抑制する ACE 阻 害薬は血漿 AII 濃度を低下させるが，長期投与下の高 血圧患者に扔いてはエスケープ現象が起こり，血漿 AII 濃度は投与前と変わらないレベルに戻ることが示 されている ${ }^{35)}$. 本研究の対象者でも, 約 $1 / 4$ の症例は ACE 阻害薬を服用していたが，その血漿 AII 濃度は 非服用群と有意差を示さなかったことから，透析患者 においても長期的には ACE 阻害薬に対し血漿 AII 濃 度にエスケープが生じることが推測される。

左室心筋重量の増加に遺伝的な素因が影響を及ぼす ことは，大規模な疫学的調査や双生児を対象とした検 討に执て示されている ${ }^{36,37)}$.また，レニンーアンジオ テンシン系の因子にはさまざまな遺伝子多型が存在す るが，その中で ACE 遺伝子の D アレルは冠動脈疾患 や腎不全の発症・進展と関連する可能性が注目されて おり ${ }^{38,39)}$ ，心肥大に関しても高血圧患者や冠動脈疾患 患者において左室心筋重量と関連を認めた成績が報告 されている ${ }^{34,40)}$. しかし，この $\mathrm{ACE}$ 遺伝子型と左室心 筋重量の関係については，健常人においては否定的な 成績が多く ${ }^{10,41,42)}$, 本研究に打いても有意な関係は認 められなかった，従来の報告 ${ }^{10,34,43)}$ では，Dアレルの存 在により血中 ACE 活性は増加するが, 血中 AII 濃度 には遺伝子型による影響は認められていない。心筇組 織中の AII 濃度と ACE 遺伝子多型の関係を検討した 成績は報告されていないが，心筋組織の $\mathrm{ACE}$ 活性は 血中と同様に DD 型で上昇していることが示されてい る ${ }^{44)}$. また, 近年, ヒトの心臓に扔いては ACE以外の 酵素によってもAII が産生されることが示されてお $\eta^{45)}$, 心肥大の進展と局所のレニンーアンジオテンシン 系およびその遺伝子多型との関連についてはさらなる 検討が必要であると思われる。

\section{結論}

慢性血液透析患者においては，血圧が LVMI に影響 する主要な因子であり,これに加えレニンーアンジオテ ンシン系の元進による血中 AII の上昇が，血圧に対す る影響とは独立した機序により LVMI の増加に関係 すると推測される。

謝辞：本研究にあたり御指導を賜りました獨協医科大学
循環器内科松岡博昭教授に深く御礼申し上げます.

\section{文献}

1）日本透析医学会統計調査委員会：わが国の慢性透析療 法の現況（1999 年 12 月 31 日現在）透析会誌 $34: 1$ 31,2001

2) Levy D, Garrison RJ, Savage DD, Kannel WB, Castelli WP: Prognostic implications of echocardiographically determined left ventricular mass in the Framingham Heart Study. N Engl J Med 322 : 1561-1566, 1990

3) Parfrey PS, Harnett JD, Griffiths SM, Taylor R, Hand J, King A, Barre PE: The clinical course of left ventricular hypertrophy in dialysis patients. Nephron 55:114-120, 1990

4) Foley RN, Parfrey PS, Harnett JD, Kent GM, Murray DC, Barre PE : Impact of hypertension on cardiomyopathy, morbidity and mortality in endstage renal disease. Kidney Int 49:1379-1385, 1996

5) Devereux RB, Alonso DR, Lutas EM, Gottlieb GJ, Campo E, Sachs I, Reichek N : Echocardiographic assessment of left ventricular. hypertrophy : comparison to necropsy findings. Am J Cardiol $57: 450$ 458, 1986

6) 太尾泰雄, 石光俊彦, 小川吉一, 寺西 恵, 松岡博昭： 慢性血液透析患者の予後と ACE 遺伝子多型性の関 連. 透析会誌 $32 ： 997-1003,1999$

7) Rigat $B$, Hubert C, Corvol P, Soubrier F : PCR detection of the insertion/deletion polymorphism of the human angiotensin converting enzyme gene (DCP 1) (dipeptidyl carboxypeptidase 1). Nucleic Acids Res $20: 1433,1992$

8) Shanmugam V, Sell KW, Saha BK : Mistyping ACE heterozygotes. PCR Methods App1 3:120-121, 1993

9) Levy D, Anderson KM, Savage DD, Kannel WB, Christiansen JC, Castelli WP : Echocardiographically detected left ventricular hypertrophy: prevalence and risk factors. The Framingham Heart Study. Ann Intern Med 108:7-13, 1988

10）瀬田 斉, 石光俊彦, 玉野宏一, 高橋正樹, 大類正巳： 正常血圧男性にお污る左室心筋重量预よび左室拡張能 に関与する因子の検討. J Cardiol 37 ：249-256, 2001

11) Washio M, Okuda S, Mizoue T, Kiyama $S$, Ando $T$, Sanai T, Hirakata H, Nanishi F, Kiyohara C, Ogimoto I, Yoshimura T, Fujishima M : Risk factors for left ventricular hypertrophy in chronic hemodialysis patients. Clin Nephrol 47:362-366, 1997

12) de Lima JJ, Abensur H, Krieger EM, Pileggi F : Arterial blood pressure and left ventricular hypertrophy in haemodialysis patients. J Hypertens 14 : 1019-1024, 1996

13) Dahan M, Siohan P, Viron B, Michel C, Paillole C, 
Gourgon R, Mignon F : Relationship between left ventricular hypertrophy, myocardial contractility, and load conditions in hemodialysis patients : an echocardiographic study. Am J Kidney Dis $30: 780-$ 785, 1997

14) Covic A, Goldsmith DJ, Georgescu G, Venning MC, Ackrill $\mathrm{P}$ : Echocardiographic findings in longterm, long-hour hemodialysis patients. Clin Nephrol $45: 104-110,1996$

15) Erturk S, Ertug AE, Ates K, Duman N, Aslan SM, Nergisoglu G, Diker E, Erol C, Karatan O, Erbay $\mathrm{B}$ : Relationship of ambulatory blood pressure monitoring data to echocardiographic findings in haemodialysis patients. Nephrol Dial Transplant 11:2050-2054, 1996

16) Cannella G, Paoletti E, Ravera G, Cassottana P, Araghi P, Mulas D, Peloso G, Delfino R, Messa P : Inadequate diagnosis and therapy of arterial hypertension as causes of left ventricular hypertrophy in uremic dialysis patients. Kidney Int $58: 260-268$, 2000

17) Conion PJ, Walshe JJ, Heinle SK, Minda S, Krucoff M, Schwab SJ : Predialysis systolic blood pressure correlates strongly with mean 24-hour systolic blood pressure and left ventricular mass in stable hemodialysis patients. J Am Soc Nephrol 7 :26582663, 1996

18) Zoccali C, Mallamaci F, Tripepi G, Benedetto FA, Cottini E, Giacone G, Malatino L : Prediction of left ventricular geometry by clinic, pre-dialysis and 24$\mathrm{h}$ ambulatory BP monitoring in hemodialysis patients : CREED investigators. J Hypertens 17 : 1751-1758, 1999

19) Port FK, Hulbert-Shearon TE, Wolfe RA, Bloembergen WE, Golper TA, Agodoa LY, Young EW : Predialysis blood pressure and mortality risk in a national sample of maintenance hemodialysis patients. Am J Kidney Dis 33: 507-517, 1999

20) Zager PG, Nikolic J, Brown RH, Campbell MA, Hunt WC, Peterson D, Van Stone J, Levey A, Meyer KB, Klag MJ, Johnson HK, Clark E, Sadler JH, Teredesai P: "U" curve association of blood pressure and mortality in hemodialysis patients. Kidney Int $54: 561-569,1998$

21) Harnett JD, Murphy B, Collingwood P, Purchase L, Kent G, Parfrey PS : The reliability and validity of echocardiographic measurement of left ventricular mass index in hemodialysis patients. Nephron 65 : 212-214, 1993

22) Huting J, Kramer W, Schutterle G, Wizemann V : Analysis of left-ventricular changes associated with chronic hemodialysis. A noninvasive follow-up study. Nephron 49:284-290, 1988
23) Parfrey PS, Harnett JD, Griffiths SM, Taylor R, Hand J, King A, Barre PE : The clinical course of left ventricular hypertrophy in dialysis patients. Nephron 55:114-120, 1990

24) London GM, Fabiani $F$ : Left ventricular dysfunction in end-stage renal disease. Echocardiographic insights. In "Cardiac Dysfunction in Chronic Uremia” ed Parfrey PS, Harnett JD, p 117-137, Kluwer Academic, Basel, Switzerland, 1992

25) Harnett JD, Kent GM, Barre PE, Taylor R, Parfrey PS: Risk factors for the development of left ventricular hypertrophy in a prospectively followed cohort of dialysis patients. J Am Soc Nephrol 4: 1486-1490, 1994

26) Dzau VJ:Tissue renin-angiotensin system in myocardial hypertrophy and failure. Arch Intern Med 153:937-942, 1993

27) Kojima M, Shiojima I, Yamazaki T, Komuro I, Zou Z, Wang Y, Mizuno T, Ueki K, Tobe K, Kadowaki $\mathrm{T}$ : Angiotensin II receptor antagonist TCV-116 induces regression of hypertensive left ventricular hypertrophy in vivo and inhibits the intracellular signaling pathway of stretch-mediated cardiomyocyte hypertrophy in vitro. Circulation 89 : 2204-2221, 1994

28) Crabos M, Roth M, Hahn AW, Erne P : Characterization of angiotensin II receptors in cultured adult rat cardiac fibroblasts. Coupling to signaling systems and gene expression. J Clin Invest $93: 2372-$ 2378, 1994

29) Sadoshima J, Qiu Z, Morgan JP, Izumo S: Angiotensin II and other hypertrophic stimuli mediated by $\mathrm{G}$ protein-coupled receptors activate tyrosine kinase, mitogen-activated protein kinase, and 90kD S6 kinase in cardiac myocytes. The critical role of $\mathrm{Ca}(2+)$-dependent signaling. Circ Res $76: 1-15$, 1995

30) Dahlof B, Pennert K, Hansson L : Reversal of left ventricular hypertrophy in hypertensive patients. A metaanalysis of 109 treatment studies. Am J Hypertens $5: 95-110,1992$

31) Schmieder RE, Martus P, Klingbeil A : Reversal of left ventricular hypertrophy in essential hypertension. A meta-analysis of randomized double-blind studies. JAMA 275 : 1507-1513, 1996

32) Cannella G, Paoletti E, Delfino R, Peloso G, Rolla D, Molinari S: Prolonged therapy with ACE inhibitors induces a regression of left ventricular hypertrophy of dialyzed uremic patients independently from hypotensive effects. Am J Kidney Dis $30: 659-664$, 1997

33) Vlahakos DV, Hahalis G, Vassilakos P, Marathias $\mathrm{KP}$, Geroulanos $\mathrm{S}$ : Relationship between left 
ventricular hypertrophy and plasma renin activity in chronic hemodialysis patients. J Am Soc Nephrol 8: 1764-1770, 1997

34) Tsukada K, Ishimitsu T, Tsuchiya N, Horinaka S, Matsuoka $\mathrm{H}$ : Angiotensin-converting enzyme gene polymorphism and cardiovascular endocrine system in coronary angiography patients. Jpn Heart J 38 : 799-810, 1997

35) Biollaz J, Brunner HR, Gavras I, Waeber B, Gavras $\mathrm{H}$, Antihypertensive therapy with MK 421: angiotensin II--renin relationships to evaluate efficacy of converting enzyme blockade. J Cardiovasc Pharmacol $4: 966-972,1982$

36) Post WS, Larson MG, Myers RH, Galderisi M, Levy D: Heritability of left ventricular mass: the Framingham Heart Study. Hypertension 30 : 10251028, 1997

37) Verhaaren HA, Schieken RM, Mosteller M, Hewitt JK, Eaves LJ, Nance WE : Bivariate genetic analysis of left ventricular mass and weight in pubertal twins (the Medical College of Virginia twin study). Am J Cardiol 68:661-668, 1991

38) Beohar N, Damaraju S, Prather A, Yu QT, Raizner A, Kleiman NS, Roberts R, Marian AJ : Angiotensin- I converting enzyme genotype DD is a risk factor for coronary artery disease. J Invest Med $43: 275-280,1995$

39) Marre M, Bernadet $P$, Gallois $Y$, Savagner F, Guyene TT, Hallab M, Cambien F, Passa P, Alhenc-Gelas $\mathrm{F}$ : Relationships between angiotensin I converting enzyme gene polymorphism, plasma levels, and diabetic retinal and renal complications. Diabetes $43: 384-388,1994$

40) Schunkert H, Hense HW, Holmer SR, Stender M,
Perz S, Keil U, Lorell BH, Riegger GA : Association between a deletion polymorphism of the angiotensin-converting-enzyme gene and left ventricular hypertrophy. N Engl J Med 330 : 16341638, 1994

41) Linhart A, Sedlacek K, Jachymova M, Jindra A, Beran S, Vondracek V, Heller S, Horky K : Lack of association of angiotensin-converting enzyme and angiotensinogen genes polymorphisms with left ventricular structure in young normotensive men. Blood Press $9: 47-51,2000$

42) Jalil JE, Piddo AM, Cordova S, Chamorro G, Braun S, Jalil R, Vega J, Jadue'P L, Lavandero S, Lastra $\mathrm{P}$ : Prevalence of the angiotensin I converting enzyme insertion/deletion polymorphism, plasma angiotensin converting enzyme activity, and left ventricular mass in a normotensive Chilean population. Am J Hypertens 12:697-704, 1999

43) Harrap SB, Davidson HR, Connor JM, Soubrier F, Corvol P, Fraser R, Foy CJ, Watt GC: The angiotensin I converting enzyme gene and predisposition to high blood pressure. Hypertension $21: 455^{-}$ 460, 1993

44) Danser AH, Schalekamp MA, Bax WA, van den Brink AM, Saxena PR, Riegger GA, Schunkert H : Angiotensin-converting enzyme in the human heart. Effect of the deletion/insertion polymorphism. Circulation $92: 1387-1388,1995$

45) Urata H, Kinoshita A, Misono KS, Bumpus FM, Husain A: Identification of a highly specific chymase as the major angiotensin II-forming enzyme in the human heart. J Biol Chem 265: 22348-22357, 1990 